\title{
Purified metallo-protease from the pathogenic haemoflagellate Cryptobia salmositica and its in vitro proteolytic activities
}

\author{
X. Zuo, P. T. K. Woo* \\ Department of Zoology, University of Guelph, Guelph, Ontario, Canada N1G 2W1
}

\begin{abstract}
The metallo-protease $(200 \mathrm{kDa})$ from Cryptobia salmositica was purified using ionexchange chromatography and gelfiltration. The purity of the enzyme was confirmed as there was only one homogeneous band using SDS-PAGE. Under in vitro conditions the purified metallo-protease completely degraded the extracellular matrix proteins (collagen types I, IV, V and laminin) and the membrane proteins isolated from rainbow trout erythrocytes. The results confirm that the $C$. salmositica metallo-protease is a histolytic enzyme and it contributes to salmonid cryptobiosis and to the direct transmission of the parasite between fish.
\end{abstract}

KEY WORDS: Cryptobia salmositica $\cdot$ Metallo-protease $\cdot$ Purification $\cdot$ Hydrolysis $\cdot$ Proteins

\section{INTRODUCTION}

Cryptobia salmositica (Katz 1951) is a pathogenic haemoflagellate of salmonid fishes on the west coast of North America (Woo \& Poynton 1995). The parasite is normally transmitted by the blood sucking leech Pisciola salmositica (see Woo 1978), but it is also transmitted directly between fish (Bower \& Margolis 1983, Woo \& Wehnert 1983). However, the mechanism for the direct transmission is unknown. Infected rainbow trout Oncorhynchus mykiss develop anaemia, exophthalmia, splenomegaly, abdominal distension with ascites, general oedema (Woo 1979) and anorexia (Li \& Woo 1991, Thomas \& Woo 1992). Cryptobiosis may result in high mortality in naturally and experimentally infected fish, but the mechanism of the disease is not well understood (Woo 1987, 1994).

The pathogenic Cryptobia salmositica has both cysteine and metallo-proteases, but the parasite has lost its metallo-protease in the avirulent strain (Zuo \& Woo 1997a). Also, the avirulent strain of $C$. salmositica (see Woo \& Li 1990) and the nonpathogenic C. catostomi (see Bower \& Woo 1977) of white suckers Catostomus commersoni have only cysteine protease and their

\footnotetext{
•Addressee for correspondence. E-mail: pwoo@uoguelph.ca
}

overall proteolytic activities are significantly lower than that of the pathogenic C. salmositica (see Zuo \& Woo 1997a). We earlier suggested that the metalloprotease contributes to pathogenesis in salmonid cryptobiosis and the cysteine protease plays an important role in protein metabolism (Zuo \& Woo 1997a, b, c).

The aim of present study was to purify the metalloprotease from the pathogenic Cryptobia salmositica and to determine its proteolytic activities.

\section{MATERIALS AND METHODS}

Parasite. The pathogenic Cryptobia salmositica was isolated from the blood of an infected rainbow trout $\mathrm{On}$ corhynchus mykiss (Walbaum) and cultured in a modified minimum essential medium at $12^{\circ} \mathrm{C}$ (Woo \& $\mathrm{Li}$ 1990) for about $7 \mathrm{wk}$. This allowed us to obtain a large number of parasites free of host cells. The parasite on short-term culture (e.g. $2 \mathrm{mo}$ ) is still pathogenic to trout (Woo \& Thomas 1991). Parasites harvested from cultures were washed 3 times in phosphate buffered saline (PBS) by centrifugation $\left(7000 \times g\right.$, at $\left.4^{\circ} \mathrm{C}, 10 \mathrm{~min}\right)$ and washed parasites were either used fresh or stored at $-100^{\circ} \mathrm{C}$ (less than $6 \mathrm{mo}$ ) prior to analysis. Storage $(6 \mathrm{mo})$ at $-100^{\circ} \mathrm{C}$ does not affect protease activity. 
Preparation of cell lysate of Cryptobia salmositica. All procedures, unless otherwise stated, were carried out at $4^{\circ} \mathrm{C}$. A suspension of washed parasites (about $10^{9}$ cells $\mathrm{ml}^{-1}$ ) in PBS containing $0.2 \%(\mathrm{v} / \mathrm{v})$ Triton $X-100$ was sonicated for about $5 \mathrm{~min}$, and followed by 3 frozen and thaw cycles. After centrifugation at $7000 \times g$ for $20 \mathrm{~min}$, the supernatant was pooled and used as crude protease extract.

Electrophoresis. Detection of proteins using SDSPAGE: Polyacrylamide gel electrophoresis (7.5\% running gel) using SDS-discontinuous buffer system (SDSPAGE) was as described by Hames (1981). A volume $(20 \mu \mathrm{l})$ of sample (containing $20 \mu \mathrm{g}$ protein of the parasite lysate or $5 \mu \mathrm{g}$ protein of the purified fraction) was mixed with an equal volume of reducing SDS-sample buffer (Bio-Rad Laboratories Ltd., Mississauga, Canada) and heated at $95^{\circ} \mathrm{C}$ for $10 \mathrm{~min}$. The electrophoresis was performed at room temperature using a Bio-Rad Miniprotean system. Protein bands were stained with silver staining (Bio-Rad Laboratories) according to the manufacture's instructions.

Detection of protease using substrate-SDS-PAGE: The substrate-SDS-gel was prepared as above except that the haemoglobin $(0.2 \% \mathrm{w} / \mathrm{v})$ was incorporated into the $7.5 \%$ running gel. The haemoglobin was extracted and prepared from the blood of an uninfected rainbow trout according to the method of Knox et al. (1993). A $40 \mu \mathrm{l}$ sample (containing $40 \mu \mathrm{g}$ protein of the parasite lysate or $10 \mu \mathrm{g}$ protein of the purified fraction) was mixed with $10 \mu \mathrm{l}$ of the non-reducing SDS-sample buffer $(0.5 \mathrm{M}$ Tris- $\mathrm{HCl}, \mathrm{pH} 6.8,10 \%$ SDS, $20 \%$ glycerol and $0.02 \%$ bromophenol blue) without boiling. Electrophoresis was performed using a BioRad Mini-protean system at $4^{\circ} \mathrm{C}$ until bromophenol blue was at the bottom of the gel (takes about $2 \mathrm{~h}$ ). After electrophoresis the gel was immersed in $2.5 \%$ (v/v) Triton X-100 for $1 \mathrm{~h}$ to remove the SDS and washed once with the incubation buffer $(0.1 \mathrm{M}$ phosphate buffer, $\mathrm{pH}$ 5.5). Protease bands were developed by immersing gels in the incubation buffer at $30^{\circ} \mathrm{C}$ for $12 \mathrm{~h}$. Zones of proteolysis appeared as clear bands against a blue background after the staining with Coomassie Blue R-250. The molecular weight of individual protease was determined from its mobility relative to those of pre-stained standard molecular weight markers (Bio-Rad Laboratories).

Protease assay. The proteolytic activity in the parasite lysate or in the purified fractions was detected using azocasein (AZC) as the substrate as described previously (Zuo \& Woo 1997a). Briefly, $100 \mu$ of the sample was incubated with $0.5 \mathrm{ml}$ of $\mathrm{AZC}\left(10 \mathrm{mg} \mathrm{ml}^{-1}\right)$ and $0.5 \mathrm{ml}$ phosphate buffer $(0.1 \mathrm{M}, \mathrm{pH} 6.0)$ at $37^{\circ} \mathrm{C}$ for $2 \mathrm{~h} .0 .2 \mathrm{ml}$ of $50 \%$ trichloroacetic acid (TCA) was then added to terminate the reaction and the tube left to stand at $4^{\circ} \mathrm{C}$ for $30 \mathrm{~min}$. The insoluble material was removed by centrifugation and the dye released was determined spectrophotometrically at $520 \mathrm{~nm}$ against the blank (the same incubation solution but with no protease sample).

Isolation and purification of a metallo-protease from crude Cryptobia salmositica lysate. Ion-exchange chromatography: The technique was as described by Yu \& Greenwood (1994) with some modifications (Zuo \& Woo 1997b). Briefly, a diethylaminoethyl (DEAE)agarose (Bio-Rad Laboratories) column $(1 \times 20 \mathrm{~cm})$ was equilibrated with $(1 / 10$ strength Mcllvaine's buffer, $\mathrm{pH}$ 6.0) and washed with the same buffer until the conductivity of the eluent and buffer were equal. The crude protease sample (parasite lysate) was applied to the column and the intracellular proteases were eluted and separated with $66 \mathrm{ml}$ of an increasing linear $\mathrm{NaCl}$ gradient $\left(0\right.$ to $0.4 \mathrm{M}$ ) at a flow rate of $18 \mathrm{ml} \mathrm{h}^{-1}$. Fractions ( $2 \mathrm{ml}$ per tube) were collected. Fractions with proteolytic activity were detected as described above and the metallo-protease and cysteine protease were identified by using protease inhibitors, 1,10-phenanthroline and E-64, respectively (Zuo \& Woo 1997a).

Gelfiltration: The technique was as described by Kohnert et al. (1988) with a slight modification. Briefly, a volume (less than $5 \mathrm{ml}$ ) of sample (the partially purified metallo-protease eluted from the DEAE-agarose column) was applied to a Sephacryl S-300 (Pharmacia Biotech Inc., Baie d'Urfé, Canada) column $(90 \times 1.6 \mathrm{~cm})$. The protease was eluted with Mcllvaine's buffer containing $50 \mathrm{mM} \mathrm{NaCl}$ at a flow rate of $22 \mathrm{ml} \mathrm{h}^{-1}$. Fractions ( $4 \mathrm{ml}$ per tube) were collected and those with proteolytic activity were detected and pooled.

Degradation of extracellular matrix proteins by purified metallo-protease. Collagen type I (purified from human placenta), collagen type IV (purified from mouse basement membranes) and collagen type $V$ (purified from human fetal membranes) were purchased from GIBCOBRL Life Technologies, Burlington, Canada. Laminin (purified from mouse basement membranes) was purchased from Sigma, Oakville, Canada. The collagen type I and the laminin (both lyophilized) were made up at $0.5 \mathrm{mg} \mathrm{ml}^{-1}$ in Trisbuffered saline (TBS) ( $\mathrm{pH} \mathrm{7.2);} \mathrm{the} \mathrm{collagen} \mathrm{type} \mathrm{IV} \mathrm{(at}$ $0.5 \mathrm{mg} \mathrm{ml}^{-1}$ in $0.5 \mathrm{M}$ acetic acid) was adjusted with $4 \mathrm{M}$ $\mathrm{NaOH}$ to $\mathrm{pH} 7.2$; the collagen type $\mathrm{V}$ (at $1.0 \mathrm{mg} \mathrm{m}^{-1}$ in TBS, pH 7.2) was diluted with the same buffer to $0.5 \mathrm{mg} \mathrm{ml}^{-1}$. A volume $(300 \mu \mathrm{l})$ of each of the proteins $\left(0.5 \mathrm{mg} \mathrm{ml}^{-1}, \mathrm{pH} 7.2\right)$ was added to $100 \mu \mathrm{l}$ of the purified metallo-protease $\left(0.1 \mathrm{mg} \mathrm{ml}^{-1}\right.$ in PBS, $\mathrm{pH} \mathrm{7.2)}$ and $100 \mu$ of PBS ( $\mathrm{pH} \mathrm{7.2)} \mathrm{containing} 20 \mathrm{mM} \mathrm{CaCl}_{2}$. The mixture was then incubated at $15^{\circ} \mathrm{C}$ until the protein was completely degraded (detected by SDS-PAGE). An aliquot $(20 \mu l)$ was taken out of the incubation medium at intervals of $0.5 \mathrm{~h}$ (for laminin) or of $2 \mathrm{~h}$ (for collagens), mixed with an equal volume of reducing 
SDS-sample buffer (Bio-Rad Laboratories) and analyzed using the SDS-PAGE as described above. Controls were the same proteins which were incubated under the same conditions except without the protease.

Degradation of protein isolated from fish erythrocyte membrane by metallo-protease. The blood cells, from an uninfected rainbow trout, were harvested by centrifugation $\left(1350 \times \mathrm{g}\right.$ at $4^{\circ} \mathrm{C}$ for $\left.10 \mathrm{~min}\right)$; the cell pellets were added to about 20 volumes of distilled water $(\mathrm{v} / \mathrm{v})$ and maintained at $4^{\circ} \mathrm{C}$ until all the red cells were ruptured (confirmed by microscopy). The haemoglobin was removed by centrifugation and the membrane pellet was washed 3 times with PBS. The membrane pellet was then added to PBS containing $0.2 \%(\mathrm{v} / \mathrm{v})$ Triton X-100 and membrane proteins were extracted as described previously (Zuo \& Woo 1996). To determine the degradation of membrane protein by the metalloprotease, $300 \mu \mathrm{l}$ of the membrane protein sample (0.5 $\mathrm{mg} \mathrm{ml}^{-1}$ in PBS, pH 7.2) was added to $100 \mu \mathrm{l}$ of the purified metallo-protease $\left(0.1 \mathrm{mg} \mathrm{ml}^{-1}\right.$ in $\mathrm{PBS}, \mathrm{pH} 7.2$ ) and $100 \mu \mathrm{l}$ of PBS containing $20 \mathrm{mM} \mathrm{CaCl}_{2}$. The mixture was then incubated at $15^{\circ} \mathrm{C}$. The degradation of membrane proteins was detected using the SDS-PAGE as described above. The control was the same membrane protein incubated under the same conditions except without the protease.

Determination of protein concentration. The protein concentrations in the parasite lysate, the purified protease samples and the membrane protein sample were determined using the method of Bradford (1976).

\section{RESULTS}

\section{Isolation and purification of metallo-protease from Cryptobia salmositica lysate}

The crude intracellular proteases of Cryptobia salmositica were fractionated and partially purified using ion-exchange chromatography. Two peaks with proteolytic activities were eluted from the DEAE-agarose column (Fig. 1A). The protease in peak I (fractions 11 to 15) was identified as a metallo-protease, because its activity was completely inhibited by the metalloprotease inhibitor 1, 10-phenanthroline; however, peak II (fractions 19 to 24 ) contained only cysteine (thiol)
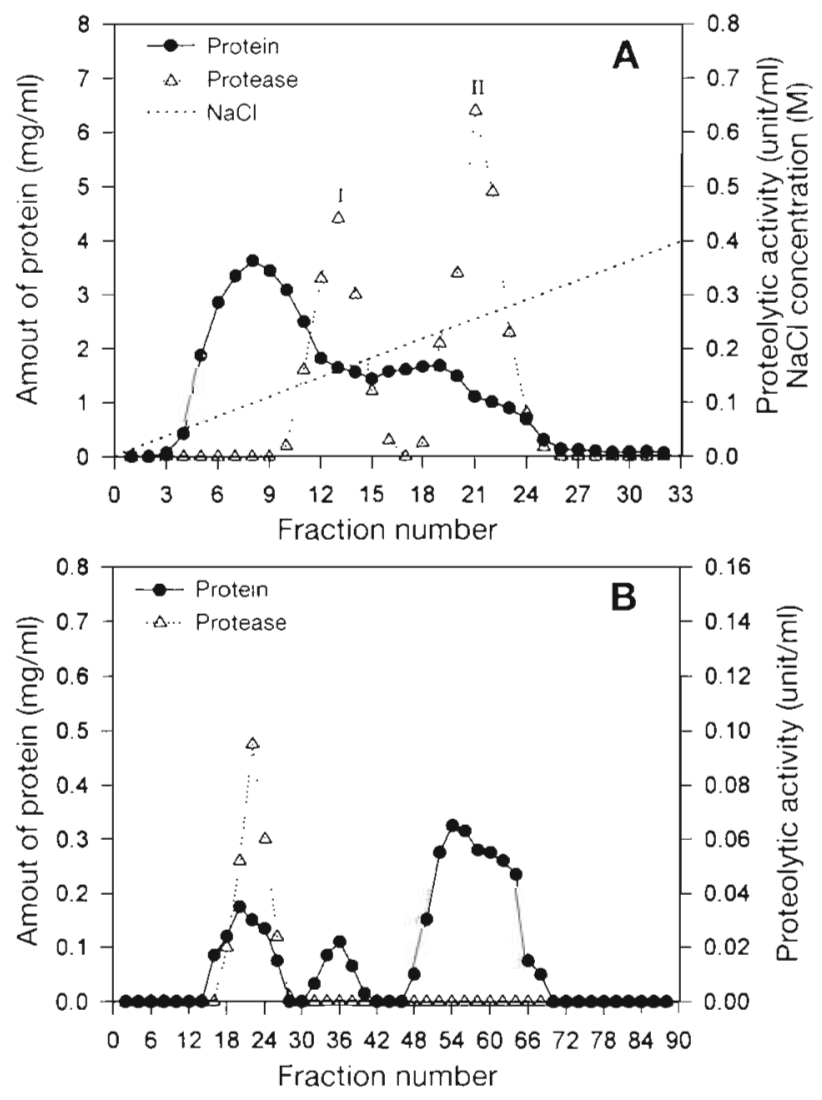

Fig. 1. Isolation and purification of the metallo-protease from the Cryptobia salmositica lysate. (A) lon-exchange chromatography; the parasite lysate (crude enzyme extract) was applied to the DEAE-agarose column and 2 peaks with proteolytic activities were eluted; peak I (fractions 11 to 15) contained metallo-protease and peak II (fractions 19 to 24) contained cysteine protease. (B) Gelfiltration: the partially purified metallo-protease feluted from the DEAE-agarose column) was applied to the Sephacryl S-300 column and 1 peak (fractions 18 to 26 ) contained the metallo-protease

protease, as its proteolytic activity was completely inhibited by the cysteine protease inhibitor E-64.

The partially purified metallo-protease was further purified using gelfiltration (Fig. 1B). Three peaks of proteins were eluted from the Sephacryl S-300 column and only 1 peak (fractions 18 to 26) had proteolytic activity and contained the metallo-protease (Fig. 1B). A summary of the purification approach is provided in Table 1.

Table 1. Purification of the metallo-proteases from the Cryptobia salmositica lysate

\begin{tabular}{|lcccccc|}
\hline Step & $\begin{array}{c}\text { Volume } \\
(\mathrm{ml})\end{array}$ & $\begin{array}{c}\text { Total protein } \\
(\mathrm{mg})\end{array}$ & $\begin{array}{c}\text { Total activity } \\
\text { (units) }\end{array}$ & $\begin{array}{c}\text { Specific activity } \\
\text { (units } \text { mg }^{-1} \text { ) }\end{array}$ & $\begin{array}{c}\text { Yield } \\
(\%)\end{array}$ & $\begin{array}{c}\text { Purification } \\
\text { (fold) }\end{array}$ \\
\hline Crude extract & 10 & 88.60 & 4.85 & 0.05 & - & 1 \\
DEAE-agarose (fractions 11-15) & 10 & 18.63 & 3.94 & 0.21 & 81.2 & 4.2 \\
Sephacryl S-300 (fractions 18-26) & 36 & 3.16 & 1.86 & 0.59 & 38.3 & 11.8 \\
\hline
\end{tabular}


There was about a 12 -fold increase in specific activity after the metallo-protease was purified and the yield was about $38 \%$ (Table 1 ).

The protein banding pattern at each step of the purification process was detected using denatured SDS-PAGE (Fig. 2). At least 20 polypeptide bands were initially found in the Cryptobia salmositica lysate (Fig. 3, lane A). However, only 4 polypeptide bands $(200,116,64$ and $53 \mathrm{kDa})$ were left in the partially purified metallo-protease (eluted from the DEAE-agarose column) (Fig. 2, lane B) and only a single polypeptide band $(200 \mathrm{kDa})$ was detected in the purified metalloprotease (eluted from the Sephacryl S-300 column) (Fig. 2, lane C). This indicates that the metallo-protease has been purified and is a homogeneous protein.

\section{Protease activity in Cryptobia salmositica lysate and purified protease fractions using substrate-gel electrophoresis}

Protease activities were detected in the samples at each step of the purification process using haemoglobin-SDS-PAGE under non-denatured conditions (Fig. 3). Five protease bands $(200,97,70,66$ and $49 \mathrm{kDa}$ ) were originally detected in the Cryptobia salmositica lysate (Fig. 3, lane A), indicating multiple intracellular proteases. After the parasite lysate was fractionated using ion-exchange chromatography, the same 5 bands remained; 4 bands $(97,70,66$ and $49 \mathrm{kDa}$ ) were cysteine proteases (Fig. 3, lane B) while

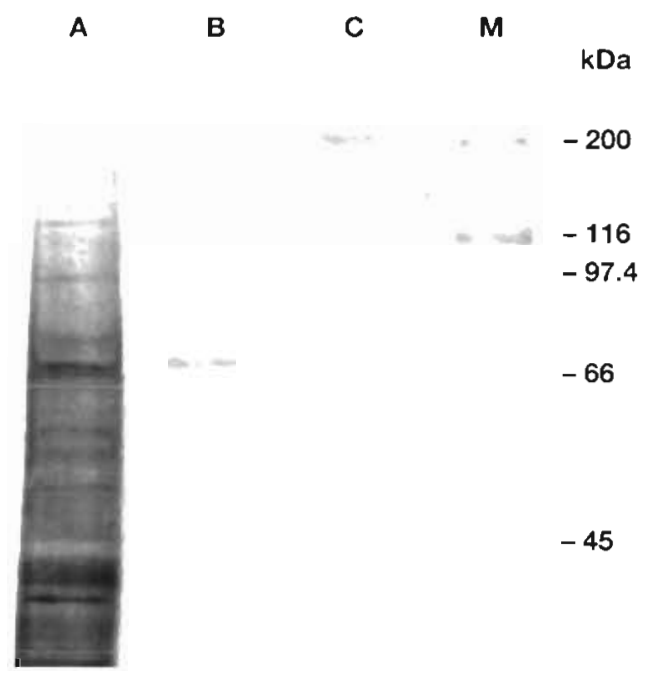

Fig. 2. SDS-PAGE of Cryptobia salmositica proteins. Lanes: A, the parasite lysate (crude enzyme extract); $B$, the partially purified metallo-protease (fractions 11 to 15 eluted from the DEAE-agarose column): $C$, the purified metallo-protease (fractions 18 to 26 eluted from the Sephacryl S-300 column); $M$, standard molecular masses ( $k D a)$

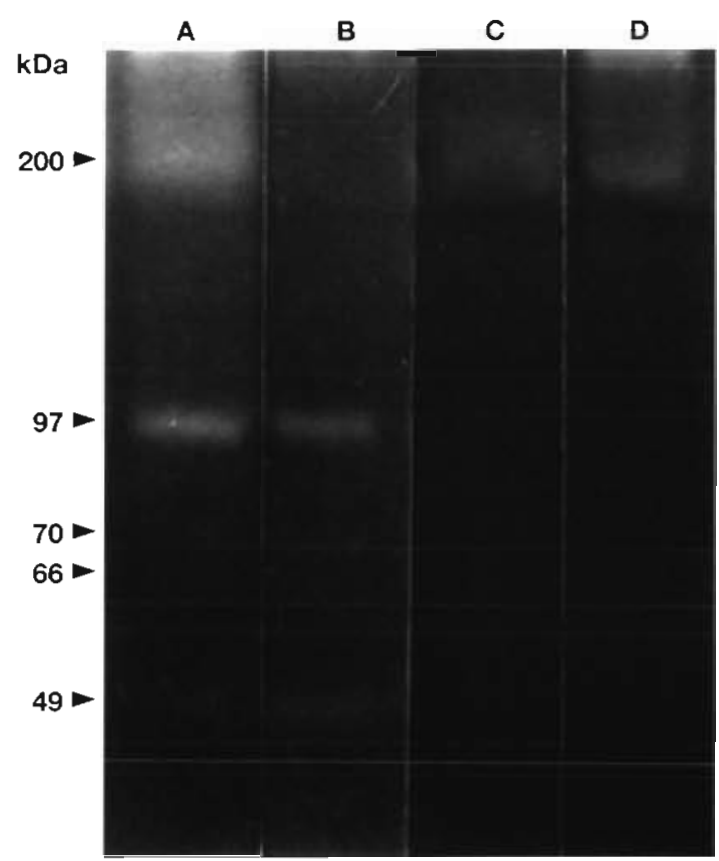

Fig. 3. Haemoglobin-SDS-PAGE (zymogram) of Cryptobia salmositica proteases. Lanes: A, the parasite lysate (crude enzyme extract); $B$, the partially purified cysteine protease (fractions 19 to 24 eluted from the DEAE-agarose column); $C$, the partially purified metallo-protease (fractions 11 to 15 eluted from the DEAE-agarose column); $D$, the purified metallo-protease (fractions 18 to 26 eluted from the Sephacryl $\mathrm{S}-300$ column). Molecular masses ( $\mathrm{kDa}$ ) of individual protease bands as indicated by arrows

the band with the highest molecular mass (200 kDa) was a metallo-protease (Fig. 3, lane C). The same protease band $(200 \mathrm{kDa})$ remained after purification of the metallo-protease using gelfiltration (Fig. 3, lane D).

\section{Degradation of collagens by purified metallo-protease}

Collagen type 1 . The collagen had 3 polypeptide bands $(260,200$ and $118 \mathrm{kDa})$ before its degradation (Fig. 4, lane A). After it was incubated with the metalloprotease, 2 of the 3 polypeptide bands (260 and $200 \mathrm{kDa}$ ) were completely degraded at $8 \mathrm{~h}$ (Fig. 4, lane E) and the major polypeptide band (118 kDa) was also completely degradated at $10 \mathrm{~h}$ (Fig. 4, lane F). The fragments produced by the degradation were not seen on the SDS-gel. However, the bands were present in the control lane (the collagen with no protease for $10 \mathrm{~h}$ ) (Fig. 4, lane G).

Collagen type IV. The collagen had 2 major polypeptide bands (190 and $165 \mathrm{kDa}$ ) (Fig. 5, lane A) before its degradation. After it was incubated with the metallo-protease, the $165 \mathrm{kDa}$ band and the $190 \mathrm{kDa}$ 


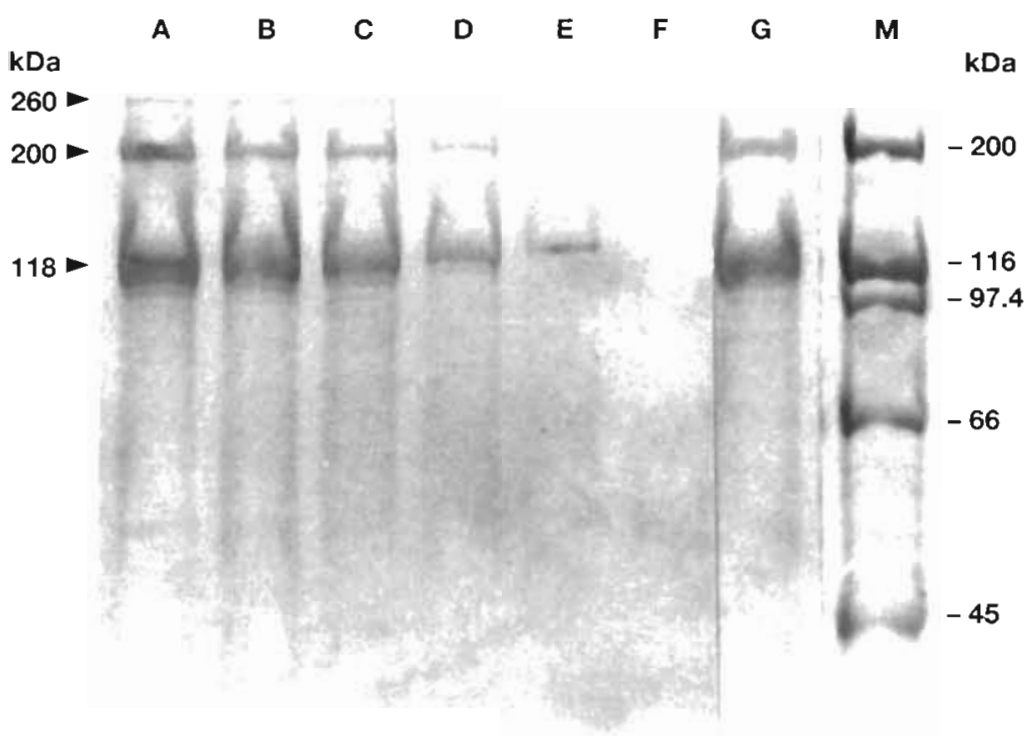

Fig. 4. Proteolytic degradation of the collagen type I. Lanes: A, B, C, D, E and $F$, the collagen incubated with the purified metallo-protease for $0,2,4,6,8$ and $10 \mathrm{~h}$, respectively; $\mathrm{G}$, the control in which the collagen was incubated under the same conditions except without the protease for $10 \mathrm{~h} ; \mathrm{M}$, standard molecular masses. Molecular masses ( $\mathrm{kDa}$ ) of individual polypeptide bands as indicated by arrows

band were completely degradated in $8 \mathrm{~h}$ (Fig. 5, lane E) and 12 h (Fig. 5, lane G), respectively. After $10 \mathrm{~h}$ of incubation 3 minor polypeptides (between 25 and $55 \mathrm{kDa}$ ) were present (Fig. 5, lanes F \& G) and these were presumed to be the degradation products of the collagen. However, in the control lane (the collagen with no protease for $12 \mathrm{~h}$ ) the protein composition was not changed (Fig. 5, lane $\mathrm{H}$ ).

Collagen type $\mathrm{V}$. The collagen had 3 major polypeptide bands $(215,110$ and $97 \mathrm{kDa}$ ) (Fig. 6, lane A) before its degradation. After it was incubated with the metallo-protease, the $110 \mathrm{kDa}$ band and the $97 \mathrm{kDa}$ band were completely degraded in $4 \mathrm{~h}$ (Fig. 6, lane C) and $6 \mathrm{~h}$ (Fig. 6, lane D), respectively. The $215 \mathrm{kDa}$ band also completely disappeared at $8 \mathrm{~h}$ (Fig. 6, lane E). However, in the control lane (collagen without protease for $8 \mathrm{~h}$ ) the protein bands remained the same (Fig. 6, lane F).

\section{Degradation of laminin by purified metallo-protease}

The laminin had a doublet polypeptide band (about $230 \mathrm{kDa}$ ) and another polypeptide band (97 kDa) before its degradation (Fig. 7, lane A). After it was incubated with the metallo-protease, the $97 \mathrm{kDa}$ band was completely degradated in $0.5 \mathrm{~h}$ (Fig. 7, lane B) and the $230 \mathrm{kDa}$ doublet disappeared at $2 \mathrm{~h}$ (Fig. 7, lane E). Two new minor polypeptide bands (about 50 and $15 \mathrm{kDa}$, respectively) appeared (Fig. 7, lanes D \& E) and they were presumed to be degradation products of laminin. However, in the control lane (the laminin incubated with no protease for $2 \mathrm{~h}$ ) its protein bands remained the same (Fig. 7, lane F).

\section{Degradation of the membrane proteins from fish erythrocytes by purified metallo-protease}

A doublet polypeptide band (about $200 \mathrm{kDa}$ ) and 3 other polypeptide bands $(180,95$ and $50 \mathrm{kDa})$ were detected in the membrane protein sample before de-
Fig. 5. Proteolytic degradation of the collagen type IV. Lanes: A, B, C, D, E, F and $G$, the collagen incubated with the purified metallo-protease for $0,2,4,6,8,10$ and $12 \mathrm{~h}$, respectively; $H$, the control in which the collagen was incubated under the same conditions except without the protease for $12 h_{;} M$, standard molecular masses. Molecular masses (kDa) of individual polypeptide bands as indicated by arrows

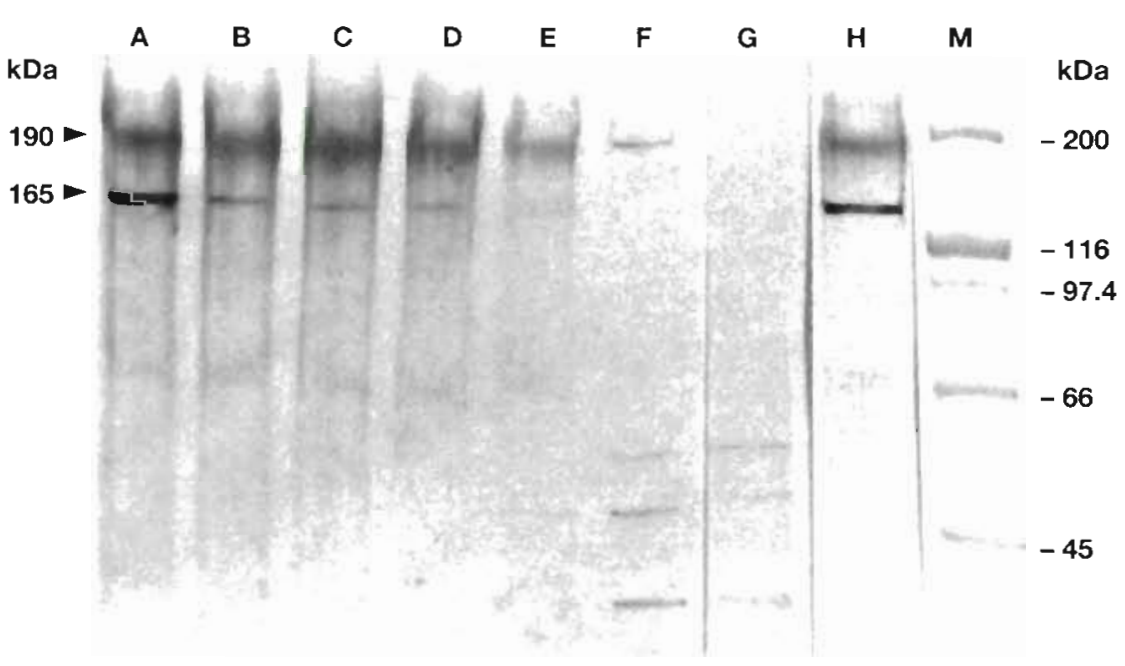




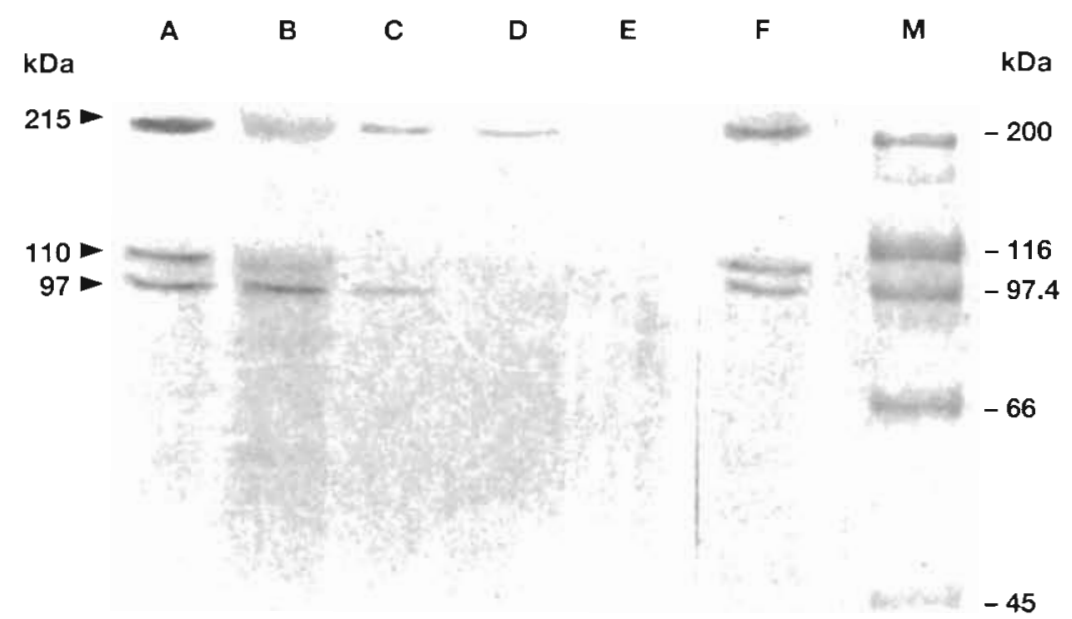

A

$\mathrm{kDa}$

230

C

D

E

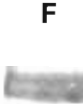

M

$\mathrm{kDa}$

$-200$

97

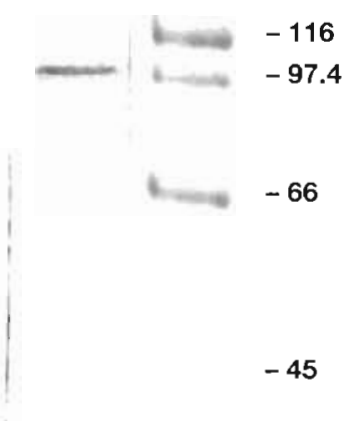

Fig. 6. Proteolytic degradation of the collagen type V. Lanes: $A, B, C, D$ and E, the collagen incubated with the purified metalloprotease for $0,2,4,6$ and 8 h, respectively; $F$, the control in which the collagen was incubated under the same conditions except without the protease for $8 h_{i} M$, standard molecular masses. Molecular masses (kDa) of individual polypeptide bands as indicated by arrows

Fig. 7. Proteolytic degradation of laminin. Lanes: A, $B, C, D$, and $E$, the protein incubated with the purified metallo-protease for $0,0.5,1,1.5$ and $2 \mathrm{~h}$, respectively; $F$, the control in which the protein was incubated under the same conditions except without the protease for $2 h_{i} M$, standard molecular masses. Molecular masses ( $\mathrm{kDa}$ ) of individual polypeptide bands as indicated by arrows

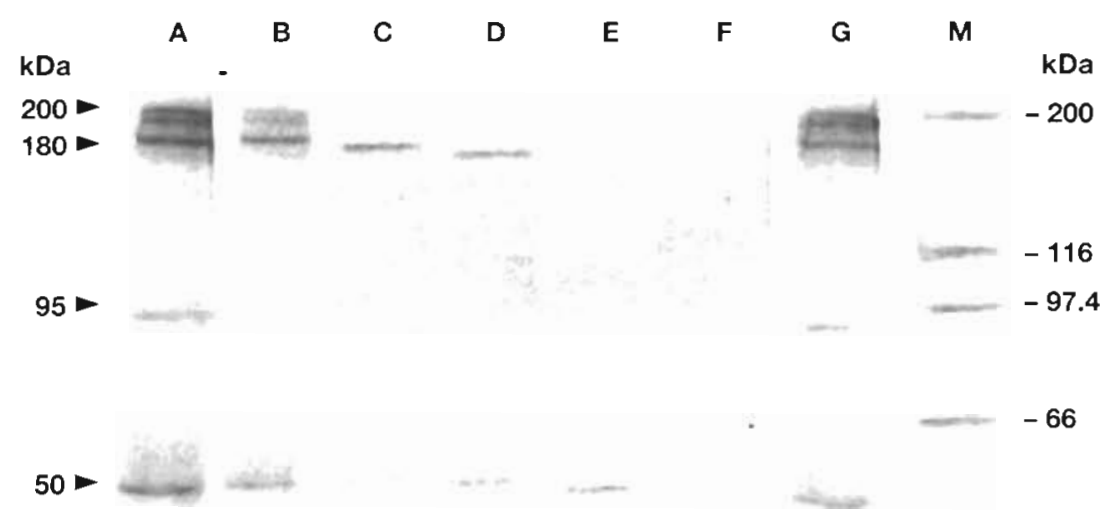

Fig. 8. Proteolytic degradation of the membrane protein in fish blood cells. Lanes: A, B, C, D, E and F, the protein incubated with the purifled metalloprotease for $0,0.5,1,1.5,2$ and $2.5 \mathrm{~h}$, respectively; $G$, the control in which the proteins was incubated under the same conditions except without the protease for $2.5 h_{i} M_{\text {, standard molec- }}$ ular masses. Molecular masses ( $k$ Da) of individual polypeptides band as indicated by arrows 
gradation (Fig. 8, lane A). After the membrane proteins were incubated with the metallo-protease, the $95 \mathrm{kDa}$ band and $200 \mathrm{kDa}$ doublet were completely degradated in $0.5 \mathrm{~h}$ (Fig. 8, lane B) and $1 \mathrm{~h}$ (Fig. 8, lane C), respectively. The $180 \mathrm{kDa}$ band disappeared at $2 \mathrm{~h}$ (Fig. 8, lane E) and the $50 \mathrm{kDa}$ band was the last to disappear at $2.5 \mathrm{~h}$ of incubation (Fig. 8, lane F). The membrane proteins incubated with the buffer only (without the protease) for $2.5 \mathrm{~h}$ still had the protein bands (Fig. 8 , lane $G$ ).

\section{DISCUSSION}

Two classes of proteases (cysteine and metalloproteases) are present in the pathogenic Cryptobia salmositica (see Zuo \& Woo 1997a, b). Using haemoglobin (substrate)-SDS-PAGE these intracellular proteases are detected as 5 enzymatic bands: 4 of them are cysteine proteases and the other is a metalloprotease (Zuo \& Woo 1997a, present study). This protease zymogram is similar to that in Trypanosoma cruzi epimastigotes (Greig \& Ashall 1990). The pathogenic C. salmositica has lost its virulence (e.g. infected fish are not anaemic) after 1 yr of serial in vitro cultivation (Woo \& Li 1990). We (Zuo \& Woo 1997a) also found a significant loss of the metallo-protease in the parasite after 10 mo of continuous in vitro culture and suggested that the decrease in metallo-protease is related to the loss of virulence. In the present study we purified the metallo-protease $(200 \mathrm{kDa})$ from the pathogenic $C$. salmositica and confirmed its proteolytic activities.

Metallo-protease is a major histolytic component in some parasitic protozoa and it may contribute to the invasion of host cells and/or tissues (McKerrow et al. 1993). Trypanosoma cruzi, a human pathogen in Central and South America, contains a metallo-protease which is mainly located in the cell membrane (Greig \& Ashall 1990, Bonaldo et al. 1991). T. cruzi trypomastigotes penetrate host cells and a surface or secreted metalloprotease is presumed to be involved in penetration of cells (Piras et al. 1985, Greig \& Ashall 1990, Bonaldo et al. 1991). The metallo-protease in trophozoite of Entamoeba histolytica, a human pathogen, readily degrades host collagens, suggesting that it also plays an important role in the invasion of host tissue (Munoz et al. 1982, 1990). A metallo-protease in the wild type (invasive type) of Vibrio anguillarum, a fish pathogen, has much higher proteolytic activity than the non-invasive mutant, suggesting that the metallo-protease plays an important role in tissue invasion (Norqvist et al. 1990).

Cryptobia salmositica causes histo-pathological lesions in fish (Bahmanrokh \& Woo 1994) and the pathogen can also transmit directly between fish in the absence of blood-sucking leeches (Woo \& Wehnert 1983). However, little is known about the mechanism of direct transmission. A collagenolytic enzyme is obviously a prerequisite, since the parasite must be able to penetrate host barriers (e.g. gills, mucous membranes, connective tissue, blood vessels) before it has access to the blood of fish. Our current hypothesis is that the secreted metallo-protease contributes to the formation of lesions in infected fish which include blisters on the body surface, as was shown by Bower \& Margolis (1983). Parasites released onto the body surface are carried in mucous strands via the water to other fish, and infections result when they penetrate the mucous membrane in the oral cavity or gills (Woo \& Wehnert 1983). Our preliminary studies showed that the $200 \mathrm{kDa}$ metallo-protease had high activities against substrates from denatured collagens (such as azocoll and gelatin) at neutral $\mathrm{pH}$ and its activities were significantly enhanced by calcium ions (Zuo \& Woo unpubl.), suggesting that the metallo-protease is perhaps a collagenolytic enzyme.

Collagen type $\mathrm{I}$ is the most common form found in a large variety of tissue and predominates in the skin (Gallop \& Paz 1975). Collagen type IV and laminin are constitutive proteins of basement membranes, while collagen type $\mathrm{V}$ is a mediator between cells and their intracellular matrices (Schulte \& Scholze 1989). In the present study the purified metallo-protease completely degraded all the 3 types of collagen and laminin under in vitro conditions (Figs. 4 to 7 ). This confirms that it is a collagenolytic enzyme. We determined its collagenolytic activities at $15^{\circ} \mathrm{C}$ since it is within salmonid physiological temperature $\left(7\right.$ to $\left.17^{\circ} \mathrm{C}\right)$. We suggest that the Cryptobia salmositica metallo-protease, like the histolytic enzyme (a metallo-protease) in the fish bacterium Aeromonas salmonicida (see Arnesen et al. 1995), may have several roles as a virulence factor and one function could be to facilitate parasite invasion through host basement membrane and tissues and this results in the direct transmission between fish.

Two basic haemolytic components ('lytic component' and 'immune complex-forming component') in the pathogenic Cryptobia salmositica are in part responsible for the anaemia in rainbow trout (Thomas \& Woo 1988). The 'lytic component' lyses red blood cells independently of antibody/complement, whereas the 'immune complex-forming component' attaches to red blood cells to form immune complexes with specific antibody and activates complement resulting in haemolysis (Thomas \& Woo 1988, 1989). These haemolytic components are also secreted by C. salmositica under in vitro conditions (Woo \& Thomas 1992). The metallo-protease is also secreted by living C. salmositica into the blood and is neutralized by the natural anti-protease $\alpha 2$-macroglobulin in fish. However, ex- 
cess of the metallo-protease in the blood is closely related to the anaemia in infected fish (Zuo \& Woo $1997 \mathrm{~b}, \mathrm{c})$. In the present study, the metallo-protease completely degraded the erythrocyte membrane proteins from a rainbow trout under in vitro conditions (Fig. 8). This indicates that proteins on the fish erythrocytes are suitable substrates for the metallo-protease and it confirms a previous investigation where we showed that the metallo-protease directly lyses of host red blood cells (Zuo \& Woo 1997b). We now conclude that the metallo-protease is also one of the causes of the anaemia in cryptobiosis and it is likely that it is the 'lytic component' detected in earlier studies (Thomas \& Woo 1988, 1989, Woo \& Thomas 1992). Further research into the biochemical nature and the functions of the C. salmositica metallo-protease would provide us with a better understanding of the disease process in salmonid cryptobiosis.

Acknowledgements. This study was supported by the grants from the Department of Fisheries and Ocean (Canada) and the Natural Sciences and Engineering Research Council (Canada) to P.T.K.W. We thank Mr Wen-Jin Yu for his technical assistance in ion-exchange chromatography.

\section{LITERATURE CITED}

Arnesen JA, Eggset G, Jørgensen TO (1995) Partial purification and characterization of extracellular metalloproteases from Aeromonas salmonicida spp. J Fish Dis 18:283-295

Bahmanrokh M. Woo PTK (1994) The histopathology of cryptobiosis in juvenile Oncorhynchus mykiss (Walbaum). In: Özcel MA, Alkan MZ (eds) Eighth International Congress of Parasitology, Abstracts, Vol Il. Turkish Society for Parasitology, Izmir, p 434

Bonaldo MC, D'Escoffier LN, Salles JM, Goldenberg S (1991) Characterization and expression of proteases during Trypanosoma cruzi metacyclogenesis. Expl Parasitol 73:44-51

Bower SM, Margolis L (1983) Direct transmission of the haemoflagellate Cryptobia salmositica among Pacific salmon (Oncorhynchus spp.). Can J Zool 61:1242-1250

Bower SM, Woo PTK (1977) Morphology and host specificity of Cryptobia catostomi n.sp. (Protozoa: Kinetoplastida) from white sucker (Catostomus commersoni) in southern Ontario. Can J Zool 55:1082-1092

Bradford MM (1976) A rapid and sensitive method for the quantitation of microgram quantities of protein utilizing the principle of protein-dye binding. Anal Biochem 72: 248-254

Gallop PM, Paz MA (1975) Posttranslational protein modifications with special attention to collagen and elastin. Physiol Rev 55:418-487

Greig S, Ashall F (1990) Electrophoretic detection of Trypanosoma cruzi peptidases. Mol Biochem Parasitol 39:31-38

Hames BD (1981) An introduction to polyacrylamide gel electrophoresis. In: Hames BD, Rickwood D (eds) Gel electrophoresis of proteins: a practical approach. IRL Press, London, p 1-91

Knox DP, Redmond DL, Jones DG (1993) Characterization of protemases in extracts of adult Haemonchus contortus, the ovine abomasal nematode. Parasitology 106:395-404
Kohnert U, Oberhoff R, Fedrowitz J, Bergmann U, Rauterberg $\mathrm{J}$, Tscheche $\mathrm{H}$ (1988) The degradation of collagen by a metalloprotease from human leucocytes. In: Horl WH, Heidland A (eds) Proteases II: potential role in health and disease. Plenum Press, New York, p 33-44

Li S, Woo PTK (1991) Anorexia reduces the severity of cryptobiosis in Oncorhynchus mykiss. J Parasitol 77:467-471

Mckerrow JH, Sun E, Rosenthal PJ, Bouvier J (1993) The proteases and pathogenicity of parasitic protozod. Annu Rev Microbiol 47:821-853

Munoz ML, Calderon J, Rojkind M (1982) The collagenase of Entamoeba histolytica. J Exp Med 155:42-51

Munoz ML, Lamoyi E, Leon G, Tovar R, Perez-Garcia J (1990) Antigens in electron-clense granules from Entamoeba histolytica as possible markers for pathogenicity. J Clin Microbiol 28:2418-2424

Norqvist A, Norman B, Wolf-Watz H (1990) Identification and characterization of a zinc metalloprotease associated with invasion by the fish pathogen Vibrio anguillarum. Infect Immun 58:3731-3736

Piras MM, Henriquez D, Piras R, Nigri S (1985) The effect of proteolytic enzymes and protease inhibitors on the interaction T. cruzi-fibroblasts. Mol Biochem Parasitol 14: $151-163$

Schulte W, Scholze H (1989) Action of the major protease from Entamoeba histolytica on proteins of the extracellular matrix. J Protozool 36:538-543

Thomas PT, Woo PTK (1988) Cryptobia salmositica: an in vitro study on the mechanism of anaemia in infected rainbow trout, Salmo gairdneri Richardson. J Fish Dis 11:425-431

Thomas PT, Woo PTK (1989) An in vitro study on the haemolytic components from Cryptobia salmositica (Sarcomastigophora: Kinetoplastida). J Fish Dis 12:389-393

Thomas PT, Woo PTK (1992) In vitro culture and multiplication of Cryptobia catostomi and experimental infection in white sucker (Catostomus commersoni). Can J Zool 70: 201-204

Woo PTK (1978) The division process of Cryptobia salmositica in experimentally infected rainbow trout (Salmo gairdneri). Can J Zool 56:1514-1518

Woo PTK (1979) Trypanoplasma salmositica: experimental infections in rainbow trout, Salmo gairdneri. Expl Parasitol $47: 36-48$

Woo PTK (1987) Cryptobia and cryptobiosis in fishes. In: Baker JR, Muller R (eds) Advances in parasitology, Vol 26. Academic Press, London, p 199-237

Woo PTK (1994) Flagellate parasites of fish. In: Kreier JP (ed) Parasitic protozoa, Vol 8. Academic Press, New York, p 1-80

Woo PTK, Li S (1990) In vitro attenuation of Cryptobia salmositica and its use as a live vaccine against cryptobiosis in Oncorhynchus mykiss. J Parasitol 76:752-755

Woo PTK, Poynton SL (1995) Diplomonadida, Kinetoplastida and Amoebida (Phylum Sarcomastigophora). In: Woo PTK (ed) Fish diseases and disorders, Vol 1, Protozoan and metazoan infections. CAB International, Wallingford, p $27-96$

Woo PTK, Thomas PT (1991) Polypeptide and antigen profiles of Cryptobia salmositica, C. bullocki and C. catostomi (Sarcomastigophora: Kinetoplastida) isolated from fishes. Dis Aquat Org 11:201-205

Woo PTK, Thomas PT (1992) Comparative in vitro studies on virulent and avirulent strains of Cryptobia salmositica (Sarcomastigophora: Kinetoplastida). J Fish Dis 15:261-266

Woo PTK, Wehnert SD (1983) Direct transmission of a haemoflagellate, Cryptobia salmositica (Kinetoplastida: Bodonia) between rainbow trout under laboratory conditions. J Protozool 30:334-337 
Yu WJ, Greenwood JS (1994) Purification and characterization of a cysteine proteinase involved in globulin hydrolysation in germinated Vicia faba L. J Exp Bot 45:261-268

Zuo X. Woo PTK (1996) Acid phosphatase in the pathogenic and nonpathogenic haemoflagellates, Cryptobia spp., of fishes. J Parasitol 82:893-899

Zuo X. Woo PTK (1997a) Proteases in pathogenic and nonpathogenic haemoflagellates, Cryptobia spp. (Sarcomastigophora: Kinetoplastida), of fishes. Dis Aquat Org 29: $57-65$

Editorial responsibility: Wolfgang Körting, Hannover, Germany
Zuo X. Woo PTK (1997b) Natural antiproteases in rainbow trout, Oncorhynchus mykiss and brook charr, Salvelinus fontinalis and the in vitro neutralization of fish $\alpha 2$ macroglobulin by the metalloprotease from the pathogenic haemoflagellate, Cryptobia salmositica. Parasitology 114:375-381

Zuo X. Woo PTK (1997c) In vivo neutralization of Cryptobia salmositica metallo-protease by $\alpha 2$-macroglobulin in the blood of rainbow trout Oncorhynchus mykiss and brook charr Salvelinus fontinalis. Dis Aquat Org 29:67-72

Manuscipt recelved: April 10, 1997

Revised version accepted: June 16, 1997 